\title{
Response to Xuan
}

\author{
Hypertension Research (2013) 36, 465-466; doi:10.1038/hr.2012.212; published online 7 March 2013
}

We are grateful to the author who shared his comments and suggestions ${ }^{1}$ regarding several issues of our meta-analysis ${ }^{2}$ to the editor. After carefully reviewing the authors' comments and checking the raw data and our original article, we are pleased to reply to and/or clarify his questions point by point.

First, because a departure from the HardyWeinberg equilibrium (HWE) in controls may indicate the existence of migration, selection and mutation in population terms, which may imply poor study quality, we excluded studies that are not in HWE from our meta-analysis. The author mentioned that there were three articles that did not deviate significantly from the HWE. ${ }^{3-5}$ After recalculation, we found that these three articles are in HWE $(P=0.066, P=0.129$, $P=0.078)$. Thus, as the author said, these three articles should have been included.

Second, the author mentioned that there were 15 additional articles that should have been included in our meta-analysis. ${ }^{3-17}$ After re-searching for articles relative to the association between C677T polymorphism and pre-eclampsia (PE), we found only four of the articles mentioned by the author. ${ }^{3-6}$ Therefore, these four studies should have been included in our meta-analysis. ${ }^{3-6}$ Another four of the studies had incomplete data and should not have been included because only data for allele $\mathrm{T}$ and TT genotype were provided. ${ }^{7-10}$ Furthermore, another seven articles were not included because they did not refer to the association between the MTHFR C677T polymorphism and PE. ${ }^{11-17}$ Otherwise, we found one other study that should also have been included in our meta-analysis. ${ }^{18}$ And so, these five studies should have been included. ${ }^{3-6,18}$

Third, the author stated that their previous study indicated that the $-677 \mathrm{~T}$ frequencies of the MTHFR gene were different between East Asian (China, Japan and Korea) and South Asian (India) populations. ${ }^{19}$ We read the meta-analysis that analyzed the relationship between the MTHFR C677T gene and myocardial infarction, which is different from our meta-analysis. And also we analyzed the heterogeneity in the Discussion section in our meta-analysis.

Taking these into account, we have now performed a new analysis by adding the five studies. $^{3-6,18}$ The pooled results showed that the MTHFR C677T polymorphism was significantly associated with $\mathrm{PE}(P=0.01$, odds ratio $(\mathrm{OR})=1.26,95 \%$ confidence interval $(\mathrm{CI})=1.04-1.52, P_{\text {heterogeneity }}=0.03$, for the dominant genetic model; $P=$ $0.02, \quad \mathrm{OR}=1.26, \quad 95 \% \quad \mathrm{CI}=1.04-1.52$, $P_{\text {heterogeneity }}=0.001$, for the recessive genetic model; $\quad P=0.004, \quad \mathrm{OR}=1.34, \quad 95 \%$ $\mathrm{CI}=1.10-1.64, P_{\text {heterogeneity }}=0.007$, for the additive genetic model). The results of the subgroup analysis showed that MTHFR 677T had the effect of increasing the PE risk for the recessive genetic model $(P<0.0001, \mathrm{OR}=$ $2.15,95 \% \quad \mathrm{CI}=1.66-2.80, \quad P_{\text {heterogeneity }}=$ $0.16)$, the additive comparison $(P<0.0001$, $\mathrm{OR}=2.56,95 \% \mathrm{CI}=1.88-3.47, P_{\text {heterogeneity }}$ $=0.24)$ and allele contrasts $(P<0.0001$, $\mathrm{OR}=1.52,95 \% \mathrm{CI}=1.31-1.77, P_{\text {heterogeneity }}$ $=0.13$ ) in the Asian population, whereas there was no evidence of an association between MTHFR C677T polymorphisms and PE observed in Caucasians.

The conclusion from this new analysis agrees with that of our previous study. ${ }^{2}$ In summary, the constructive comments provided help to our study to reach more persuasive conclusions.

\section{CONFLICT OF INTEREST}

The authors declare no conflict of interest.

$$
\begin{array}{r}
\text { Wei-wei Chang }{ }^{1,5}, \text { Xiao-ping Xia }{ }^{2,3,5} \\
\text { and Yun-xia Cao }{ }^{4}
\end{array}
$$

${ }^{1}$ Department of Preventive Medicine, Wannan Medical College, Wuhu, China; ${ }^{2}$ Reproductive Medicine Center, The First Affiliated Hospital of Anhui Medical University, Hefei, China; ${ }^{3}$ Department of Gynaecology and Obstetrics, the Liu'an
People's Hospital, Liu'an, China and ${ }^{4}$ Department of Gynaecology and Obstetrics, The First Affiliated Hospital of Anhui Medical University, Hefei, China ${ }^{5}$ These authors contributed equally to this work. E-mail: aydcaoyunxia@163.com

1 Xuan C, Lun LM. Association between the methylenetetrahydrofolate reductase $\mathrm{C} 677 \mathrm{~T}$ polymorphism and susceptibility to preeclampsia: the need for data clarification in a recent meta-analysis. Hypertens Res 2013; 36: 463-464.

2 Xia XP, Chang WW, Cao YX. Meta-analysis of the methylenetetrahydrofolate reductase $\mathrm{C} 677 \mathrm{~T}$ polymorphism and susceptibility to pre-eclampsia. Hypertens Res 2012; 35: 1129-1134.

3 Rigo J, Nagy B, Fintor L, Tanyi J, Beke A, Karadi I, Papp Z. Maternal and neonatal outcome of preeclamptic pregnancies: the potential roles of factor $V$ Leiden mutation and 5,10 methylenetetrahydrofolate reductase. Hypertens Pregn 2000; 19: 163-172.

4 Livingstone JC, Barton JR, Park V, Haddad B, Philips O, Sibai BM. Maternal and fetal inherited thrombophilias are not related to the development of severe preeclampsia. Am J Obstet Gynecol 2001; 185: 153-157.

5 Wang SM, Wang LG, Liu XJ, Wu AH, Yu JC, Shi H. Investigation on the association between MTHFR gene C677T polymorphism and pre-eclampsia. Matern Child Health Care China 2008; 23: 552-554.

6 Stonek F, Hafner E, Philipp K, Hefler LA, Bentz EK, Tempfer CB. Methylenetetrahydrofolate reductase C677T polymorphism and pregnancy complications. Obstet Gynecol 2007; 110(Part 1): 363-368.

7 D'Elia AV, Driul L, Giacomello R, Colaone R, Fabbro D, Di Leonardo C, Florio P, Petraglia F, Marchesoni D, Damante G. Frequency of factor $\mathrm{V}$, prothrombin and methylenetetrahydrofolate reductase gene variants in preeclampsia. Gynecol Obstet Invest 2002; 53: 84-87.

8 Fabbro D, D'Elia AV, Spizzo R, Driul L, Barillari G, Di Loreto C, Marchesoni D, Damante G. Association between plasminogen activator inhibitor 1 gene polymorphisms and preeclampsia. Gynecol Obstet Invest 2003; 56: 17-22.

9 Driul L, Damante G, D'Elia A, Ianni A, Springolo F, Marchesoni D. Genetic thrombophilias and uterine artery Doppler velocimetry and preeclampsia. Int J Gynaecol Obstet 2005; 88: 265-270.

10 Kahn SR, Platt R, McNamara H, Rozen R, Chen MF, Genest Jr J, Goulet L, Lydon J, Seguin L, Dassa C, Masse A, Asselin G, Benjamin A, Miner L, Ghanem A, Kramer MS. Inherited thrombophilia and preeclampsia within a multicenter cohort: the Montreal Preeclampsia Study. Am J Obstet Gynecol 2009; 200: 151.e1-9;. discussion e1-5.

11 Kupferminc MJ, Fait G, Many A, Lessing JB, Yair D, Bar-Am A, Eldor A. Low-molecular-weight heparin for the prevention of obstetric complications in women 
with thrombophilias. Hypertens Pregnancy 2001; 20 $35-44$.

12 Alfirevic Z, Mousa HA, Martlew V, Briscoe L, PerezCasal M, Toh $\mathrm{CH}$. Postnatal screening for thrombophilia in women with severe pregnancy complications. Obstet Gynecol 2001; 97: 753-759.

13 Mello G, Parretti E, Marozio L, Pizzi C, Lojacono A, Frusca T, Facchinetti F, Benedetto $C$. Thrombophilia is significantly associated with severe preeclampsia: results of a large-scale, case-controlled study. Hypertension 2005; 46: 1270-1274.

14 Demir SC, Evruke C, Ozgunen T, Kadayifci O, Altintas $\mathrm{U}$, Kokangul S. The relationship between pregnancy induced hypertension and congenital thrombophilia. Saudi Med J. 2006; 27: 1161-1166.

15 Klai S, Fekih-Mrissa N, El HS, Kaabechi N, Nsiri B, Rachdi R, Gritli N. Association of MTHFR A1298C polymorphism (but not of MTHFR C677T) with elevated homocysteine levels and placental vasculopathies. Blood Coagul Fibrinolysis 2011; 22: 374-378.

16 Mislanova C, Martsenyuk O, Huppertz B, Obolenskaya M. Placental markers of folate-related metabolism in preeclampsia. Reproduction 2011; 142: 467-476.

17 Said JM, Higgins JR, Moses EK, Walker SP, Monagle PT, Brennecke SP. Inherited thrombophilias and adverse pregnancy outcomes: a case-control study in an Australian population. Acta Obstet Gynecol Scand 2012; 91: 250-255.

18 Yoshida A, Miura K, Nakayama D, Masuzaki H. Correlation between preeclampsia and prevalence of polymorphism of angiotensinogen, methyleneteterahydrofolate reductase and factor $\mathrm{V}$, prothrombin genes among Japanese women. Acta Medica Nagasakiensia 2008; 53: 37-41.

19 Xuan C, Bai XY, Gao G, Yang Q, He GW. Association between polymorphism of methylenetetrahydrofolate reductase (MTHFR) C677T and risk of myocardial infarction: a meta-analysis for 8,140 cases and 10,522 controls. Arch Med Res 2011; 42: 677-685. 